Uludag Univ. J. Fac. Vet. Med.

34 (2015), 1,2: 25-33

\title{
Ratlarda Kardiyak Mastositlerinin İstatistiksel Olarak Dağılımı ve Heterejonitesi
}

\author{
Özlem EREKLİ $\dot{I}^{\mathbf{1}} \quad$ Kenan ÇINAR $^{1}$
}

Geliş Tarihi: 11-11-2015

Kabul Tarihi: 04-12-2015

\begin{abstract}
Özet: Bu çalışmada Wister Albino türü sıçanlarda kardiyak mast hücrelerinin sayısal dağılımı ve altı farklı tespit çözeltisinin (Bouin, \%10 Formalin, Schaudin, Orth, Alkolik Formalin ve Carnoy) bu hücrelerin boyanma özelliklerine olan etkisinin belirlenmesi amaçlandı.

Mast hücrelerinin demonstrasyonu için Toluidin Blue (TB), Thionin ve Alcian Blue/Safranin O (AB/SO) boya metotları uygulandı. Boyanan kesitlerde, tüm preparatlardaki mast hücrelerinin sayısal yoğunluğu oküler mikrometre yardımıyla belirlendi. Daha sonra elde edilen veriler $1 \mathrm{~mm}^{2}$ lik alandaki mast hücre sayısına dönüştürüldü. $\mathrm{TB} / \mathrm{Thionin} / \mathrm{AB} / \mathrm{SO}$ ile boyanan mast hücre sayılarının atriyum ve ventrikuluslardaki yoğunlukları tespit edildi. Mast hücreleri Carnoy tespit çözeltisi ile Toluidine Blue'da, Orth tespit çözeltisiyle ise Thionin ve AB/SO'de en fazla sayısal sonucu vermiştir.

Altı fiksatifin de uygulanması sonucunda mast hücre granülleri en belirgin olarak $\mathrm{AB} / \mathrm{SO}$ boyanması ile gözlendi.

Mast hücre şekillerinin, farklı tespit çözeltilerine göre farklılık gösterdiği saptandı. \%10 Formalin tespit çözeltisi hariç diğer tespit çözeltileri ile fiske edilmiş doku örnekleri, Toluidine Blue boyası ile boyandıklarında mast hücrelerinin metakromazi gösterdikleri tespit edildi. Carnoy ve Schaudin tespit çözeltilerinin kullanıldığı doku örneklerinde, Thionin ile boyandıklarında metakromazi gösteren mast hücreleri görüldü.
\end{abstract}

Anahtar Kelime: Rat, mast hücresi, kalp, heterojenite, fikzasyon.

\section{Statistical Distribution and Heterogenicity of the Cardiac Mast Cells in Rats}

\begin{abstract}
This study was aimed to determine the numerical distribution of cardiac mast cells and the effect of six different fixatives (Bouin, 10\% Formalin, Schaudin, Orth, Alcoholic Formalin and Carnoy) on the staining properties of these cells in Albino Wistar rats.

Toluidine Blue (TB), Thionin and Alcian Blue / Safranin O (AB/SO) staining procedures were employed to demonstrate the cardiac mast cells. Numerical density of mast cells was determined through the instrument of the ocular micrometer. Then, the data obtained were converted to the number of mast cells in a $1 \mathrm{~mm}^{2}$ area. Numerical density of TB/Thionin/AB/SO-stained mast cells was detected in atrium and ventricles.

Mast cells were detected to outnumber in Carnoy-fixed and TB-stained sections and in Orth-fixed and AB/SO, Thionin stained sections.

Mast cell granules were demonstrated more specifically in AB/SO staining as a result of the implementation of six different fixatives.

Shapes of mast cells were found to vary by different fixative solutions. Mast cells were observed to stain metachromatically when sections fixed with other fixative solutions except for $10 \%$ Formalin fixative solution were stained with TB. In a similar way, mast cells were shown to stain metachromatically when sections fixed with Carnoy and Schaudin fixative solutions were stained with Thionin.
\end{abstract}

Key Words: Rat, mast cell, heart, heterogeneity, fixation.

1 Süleyman Demirel Üniversitesi, Fen Edebiyat Fakültesi Biyoloji Bölümü Doğu Yerleşkesi Çünür/ISPARTA, zlmrkl@gmail.com 


\section{Giriş}

Mast hücreleri $\operatorname{IgE}$ ve $\operatorname{IgG}$ alt siniflarını bağlayan membran reseptörlerine sahip, aşırı duyarlılık reaksiyonlarında, paraziter hastalıklarda ve neoplazmlara karşı savunmada rol alan hücrelerdir ${ }^{3,19}$. Mast hücresi proteazlarının dokudaki humoral ve hücresel olayların düzenlenmesinde önemli rol oynamaktadır. Mast hücreleri vazopermeabilite, inflamatuar hücre cevab1, koagulasyon, doku yıkımı, intersellüler protein ve peptid işlenmesi ve inflamatuar mediatörlerin hidrolizi gibi önemli görevler üstlenmektedir ${ }^{33}$.

Mast hücreleri vücuttaki dokularda kan damarları, sinirler ve dış çevre ile ilişkide olan yüzeylerde yerleşik olarak bulunurlar ${ }^{33}$. Mast hücreleri orjinleri, yerleşim yerleri, kullanılan tespit solüsyonuna verilen cevap, taşıdığı glikozaminoglikanlarının türü, intragranüler serin proteinazın türü ${ }^{4,8,29}$ histokimyasal farkl11ıklar, fonksiyonel kriterler ve hücrelerin morfolojik özellikleri gibi unsurlar göz önüne alındığında, bağ doku mast hücresi ve mukozal mast hücresi olmak üzere iki alt gruba ayrılmaktadır, ${ }^{6,21,22}$. Birinci tip, granülleri içinde kanın pıhtılaşması$\mathrm{n} 1$ engelleyen ve sülfatlanmış bir glikozaminoglikan olan heparin bulunduran bağ dokusu mast hücresi, ikinci tip ise granüllerinde heparin yerine kondroitin sülfat bulunduran mukozal mast hücresidir. Mast hücre granüllerinde pıhtılaşmaya engelleyen heparinden başka damar geçirgenliğini arttıran histamin, eozinofil ve nötrofillerin kandan bağ dokuya göç etmesini uyaran EFC (Eozinofil kemotaktik faktör) ve NCF (Nötrofil kemotaktik faktör) bulunur ${ }^{1}$.

Mast hücreleri birçok dokuda olduğu gibi kalpte de infeksiyonlara ve inflamatuar uyarılara degranülasyon ile yanıt verir. Miyokardta infarkt alanının iyileşmesinde mast hücreleri, makrofajlar ile birlikte görev yapmaktadır ${ }^{27}$.

Mast hücre sekresyonunu tetikleyen faktörler; Anaflotoksinler (C3a ve C5ahipersensitivite durumunda), bakteriler (E.coli), kimyasallar, ilaçlar (lokal anestezikler, nöromüsküler birleşme bölgesi blokerleri), sitokinler, serbest radikaller, toksinler, IgE ve antijen, hormonlar, büyüme faktörleri (SCF-kök hücresi büyüme faktörü), nörotransmitter maddeler (asetilkolin), virüsler (kızamık, grip), fiziksel koşullar (soğuk, egzersiz, basınç), radyasyon olarak siralanabilir ${ }^{33}$.

Mast hücreleri doku homeostazisinde, dokunun yeniden şekillenmesinde ve onarımında etkili hücreler olduğu gözlenmiştir. Kalp dokusunda bulunmasiyla miyopatik kalplerde hem tanı hem de tedavinin değişmesine neden olmaktadır ${ }^{2}$. Koroner spazma ${ }^{15}$ dahil olan mast hücrelerinin ise kardiyomiyopati ${ }^{28}$, aterosklero$\operatorname{sis}^{25}$ ve deneysel miyokard iskemine ${ }^{16,17,23}$ dahil olduğu öne sürülmüştür. İskemik kalp hastalığ 1 olanlarda, aterosklerotik plaklar dâhil kalp dokusunda mast hücrelerinin sayısı ve yoğunluğu $\operatorname{artar}^{10}$.

Bu çalışmada kullanılan farklı tespit çözeltileriyle sıçan kardiyak mast hücrelerinin atriyum ve ventrikulusta sayısal dağılımı, morfolojik olarak şeklinin belirlenmesi ve tespit çözeltilerinin boyanma üzerine etkilerinin belirlenmesi amaçlandı.

\section{Materyal ve Metot}

Bu çalışmada Süleyman Demirel Üniversitesi Deney Hayvanı Üretimi ve Deneysel Araştırma Laboratuvarından temin edilen 5 adet Wistar Albino türü sıçan kalbi materyal olarak kullanıldı. Çalışma, Süleyman Demirel Üniversitesi Hayvan Deneyleri Etik Kurulu (HADYEK) onay1 (karar tarihi: 28.09.2010/ karar no: 01) kapsamında gerçekleştirildi.

Alınan kalp dokularının tespiti için Bouin, \%10 Formalin, Schaudin, Orth, Alkolik Formalin ve Carnoy olmak üzere altı farklı fiksatif kullanıld ${ }^{20}$

Orth ve $\% 10$ Formalin solüsyonlarında 48 saat tespit edildikten sonra 24 saat akar suda yıkanan dokular, dereceli alkol serilerinden geçirilerek dehidre edildi ve parafinde blokland1. Carnoy solüsyonunda 90 dakika, Alkolik Formalin solüsyonunda 4 saat, Schaudin ve Bouin solüsyonlarında 16 saat tespit edilen ve rutin histolojik doku takibi aşamasından geçirilen örnekler parafinde bloklandı.

Dokulardan $5 \mu \mathrm{m}$ kalınlığında alınan kesitlere, mast hücrelerinin belirlenmesi amaciyla Alcian Blue/Safranin ${ }^{9}$, Thionin ${ }^{7}$ ve Toluidine Blue $^{34}$ boyama yöntemleri uygulananak ilgili alanlardan fotoğraf çekimi yapıldı. Hazırlanan preparatlar 1ș1k mikroskobunda incelendi. Oküler mikrometre yardımıyla preparatların alanları atriyum ve ventrikulus bölgesi olmak üzere iki ayrı alanda hesaplandı ve mast hücre sayımları yapıldı. Daha sonra, preparatların alanları $1 \mathrm{~mm}^{2}$ ye düșen mast hücre sayısına dönüștürüldü. Veriler, "Minitab-17" istatistik programına girildi. Preparatlar arasındaki mast hücre sayılarinın farklılıkları "One Way Anova" testi ile belirlendi. 


\section{Bulgular}

\section{\% 10 Formalin Fikzasyonu:}

$\mathrm{Bu}$ fikzasyonun uygulandığı dokulardan alınan kesitlere yapılan $\mathrm{AB} / \mathrm{SO}$ boyaması sonucunda atriyumda yuvarlak, oval veya armut şeklinde (Şekil-1.a); ventrikulusta oval veya uzun-mekik (Şekil-1.b); epikartta ise yuvarlak (Şekil-1.c) şekilli mast hücreleri gözlendi. Thionin boyası ile atriyumda damla şeklinde (Şekil1.d) veya oval; ventrikulusta granüller dağınık oval, uzun ve düzensiz (Şekil-1.e); epikatta ise oval (Şekil-1.f) mast hücrelerine rastlandı. Toluidine Blue uygulaması sonucunda ise atriyumda oval; ventrikulusta düzensiz ve uzun (Şekil-1.g); epikartta ise mekik şeklinde (Şekil-1.h) ve oval görünümlü mast hücrelerine rastlandı.

\section{Alkolik Formalin Fikzasyonu:}

$\mathrm{AB} / \mathrm{SO}$ ile boyanan atriyum kesitlerinde oval veya düzensiz (Şekil-2.a), yuvarlak; ventrikulusta düzensiz, oval (Şekil-2.b), yuvarlak; epikartta ise uzun yapılı mast hücreleri gözlendi. Thionin uygulaması sonucunda atriyumda oval, yuvarlak (Şekil-2.c), düzensiz; ventrikulusta uzun, yuvarlak, granül dağınık ve uzun (Şekil-2.d); epikartta ise yuvarlak veya düzensiz mast hücreleri saptandı. Toluidine Blue boyaması ile atriyumda yuvarlak veya oval (Şekil2.e); ventrikulusta oval-dağınık granüllü (Şekil2.f); epikartta ise uzun veya oval mast hücreleri tespit edildi.

\section{Bouin Fikzasyonu:}

$\mathrm{Bu}$ fikzasyon ve $\mathrm{AB} / \mathrm{SO}$ boya uygulaması sonucunda atriyumda oval ve yuvarlak; ventrikulusta oval (Şekil-3.a) ve yuvarlak; epikartta yuvarlak mast hücrelerine rastlandı. Thionin ile boyanan atrium örneklerinde armut şeklinde ve yuvarlak (Şekil-3.b); ventrikulusta uzundüzensiz (Şekil-3.c); epikartta oval veya yuvarlak mast hücre tipine rastlandı. Toluidine Blue uygulamasında ise atriyumda granülleri dağınık ya da düzenli-yuvarlak (Şekil-3.d) ve oval; ventrikulusta uzun düzensiz (Şekil-3.e-f.) veya oval biçimli mast hücreleri tespit edildi.

\section{Carnoy Fikzasyonu:}

Atriyum kesitlerine $\mathrm{AB} / \mathrm{SO}$ uygulamas1 sonucunda oval, granülleri dağınık-oval veya düzensiz (Şekil-4.a); ventrikulusta uzundüzensiz, oval ve armut (Şekil-4.b); epikartta ise şekillinde mast hücreleri gözlendi. Thionin ile boyanan atriyum örneklerinde yuvarlak ve oval (Şekil-4.c); ventrikulusta yuvarlak, düzensizdağınık granüllü; epikartta ise oval-granülleri dağınık mast hücrelerine rastlandı. Toluidine Blue uygulamas1 atriyumda oval ve yuvarlak; ventrikulusta uzun veya oval (Şekil-4.d), düzensiz; epikartta ise uzun veya düzensiz mast hücreleri saptandi.

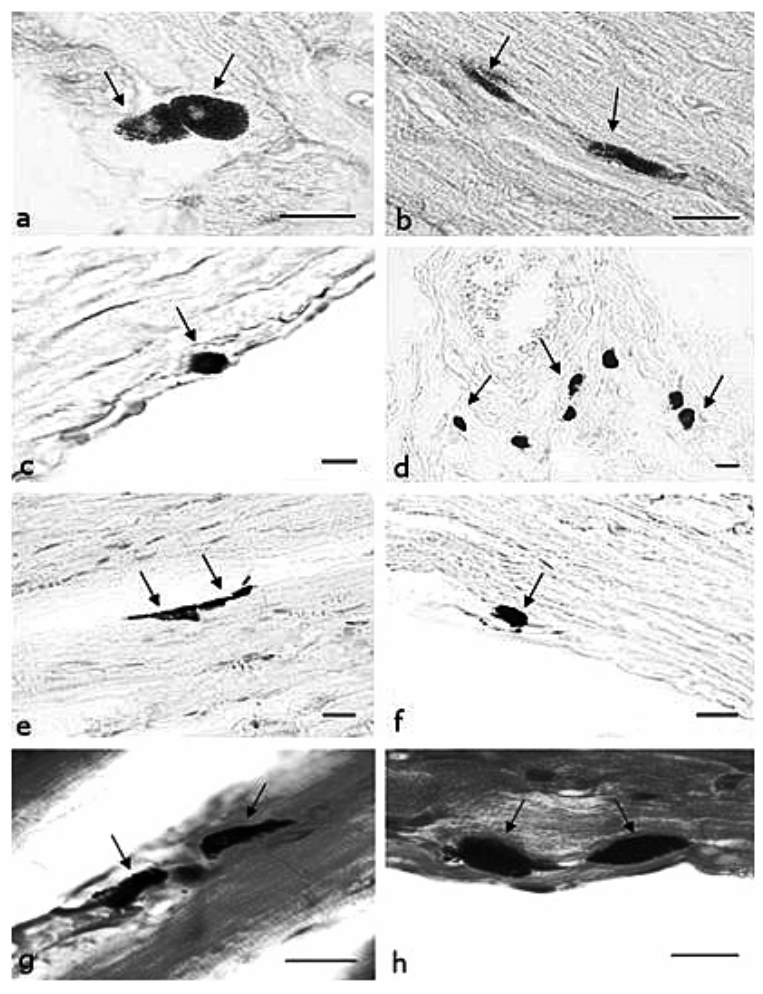

Şekil-1.a. Atriyumda safranin (+) mast hücrele-

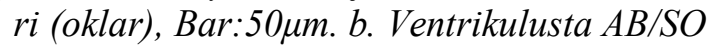

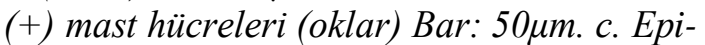
kartta Safranin (+) mast hücresi (ok) Bar: $50 \mu m$. d. Atriyumda Thionin (+) mast hücreleri (oklar) Bar: 50um. e. Ventrikulusta Thionin (+)

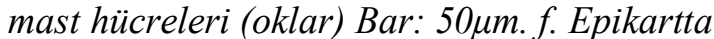

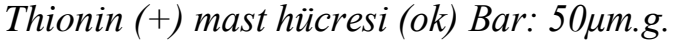
Ventrikulusta T.B (+) mast hücresi(oklar) Bar:

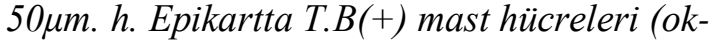
lar) Bar: $50 \mu m$.

Figure-1.a. Safranine (+) staining for mast cells (arrows) in atria, Scale bar: $50 \mu \mathrm{m} . b$. $\mathrm{AB} / \mathrm{SO}(+)$ staining for mast cells (arrows) in

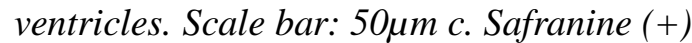
staining for mast cells (arrow) in epicardium. Scale bar: $50 \mu \mathrm{m}$. d. Thionin (+) staining for

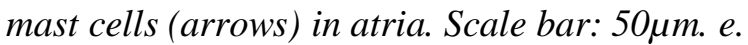
Thionin (+) staining for mast cells (arrows) in

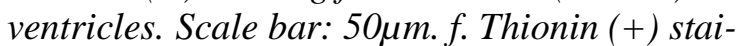
ning for mast cells (arrow) in epicardium. Scale bar: $50 \mu \mathrm{m} . \mathrm{g}$. T.B (+) staining for mast cells (arrows) in ventricles. Scale bar: $50 \mu \mathrm{m}$. h. T.B $(+)$ staining for mast cells (arrows) in epicardium. Scale bar: $50 \mu \mathrm{m}$. 


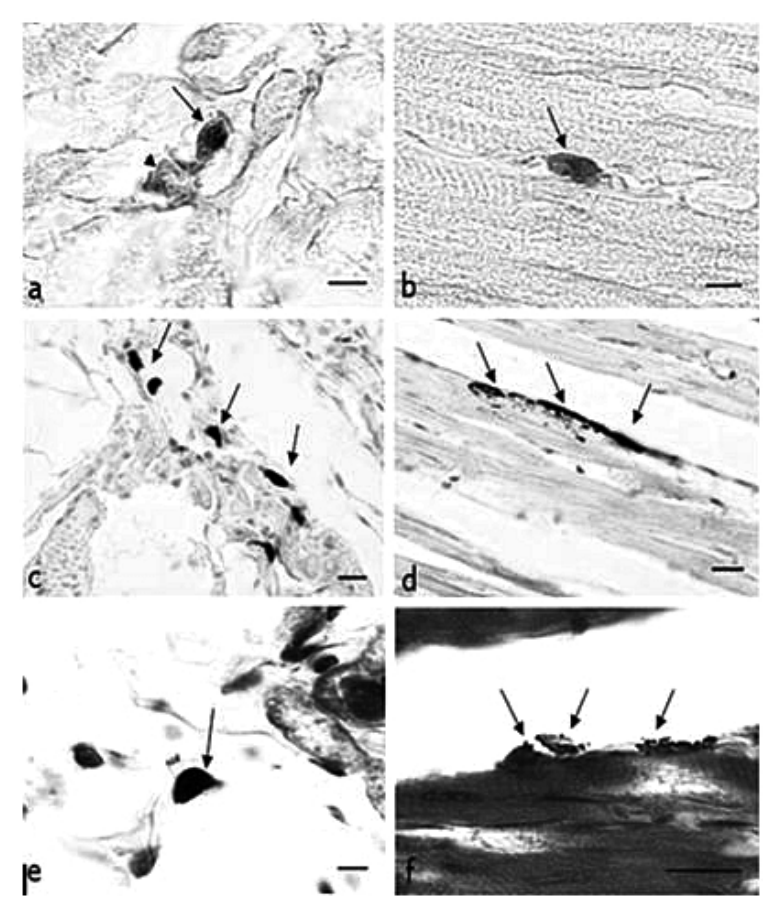

Şekil-2.a. Atriyumda $A B(+)$ (ok başı), $A B / S O$

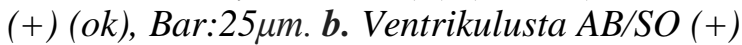
mast hücresi (ok) Bar: $25 \mu m$. c. Atriyumda Thionin (+) mast hücreleri (oklar), Bar: 50 $\mu$ m. d. Ventrikulusta Thionin (+) mast hücreleri (oklar), Bar: $50 \mu$ m. e. Atriyumda T.B (+) mast

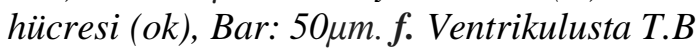

(+) mast hücreleri (oklar), Bar: 50 $\mathrm{m}$.

Figure-2.a. $A B(+)$ staining for mast cells (arrow hit), $A B / S O(+)$ staining for mast cells (arrow) in atria. Scale bar: $25 \mu \mathrm{m}$. b. AB/SO (+) staining for mast cells (arrow) in ventricles. Scale bar: $25 \mu m$. c. Thionin (+) staining for mast cells (arrows) in atria. Scale bar: $50 \mu \mathrm{m}$. $\boldsymbol{d}$. Thionin ( + ) staining for mast cells (arrows) in

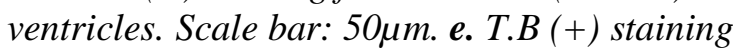
for mast cells (arrow) in atria. Scale bar: $50 \mu \mathrm{m}$. f. T.B (+) staining for mast cells (arrows) in ventricles. Scale bar: $50 \mu \mathrm{m}$.

\section{Orth Fikzasyonu:}

$\mathrm{Bu}$ fiksatif ile fiske edilerek $\mathrm{AB} / \mathrm{SO}$ boyanan atriyum, ventrikulus ve epikart kesitlerinde düzensiz (Şekil-5.a), armut veya yuvarlak görünümlü mast hücreleri tespit edildi. Thionin uygulaması sonucunda atriyumda armut şeklinde veya oval; ventrikulusta granüller dağınık düzensiz-uzun (Şekil-5.b); epikartta granüller dağınık ve uzun-düzensiz (Şekil-5.c) mast hücreleri gözlendi. Toluidine Blue boyası ile boyanan doku örneklerinde atriyumda oval; ventrikulusta düzensiz (Şekil-5.d), uzun; epikartta granülleri dağınık ve uzun-düzensiz mast hücrelerine rastlandi.

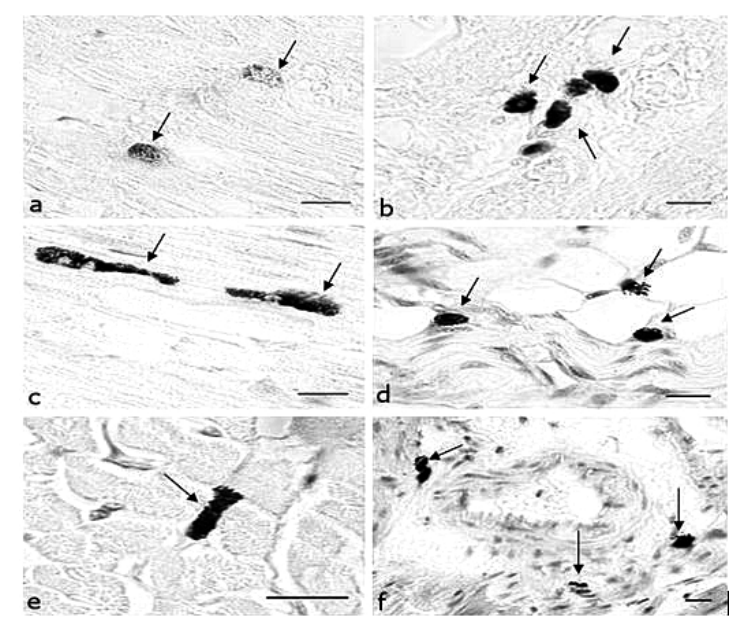

Şekil-3.a. Ventrikulusta AB/SO (+) mast hücre-

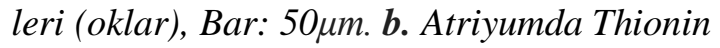

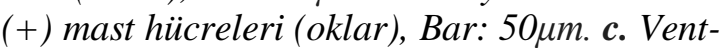
rikulusta Thionin (+) mast hücreleri (oklar),

Bar: $50 \mu m$. d. Atriyumda T.B (+) mast hücreleri

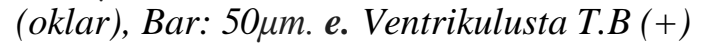
mast hücresi (ok), Bar: 50 $\mu$ m. f. Ventrikulusta T.B (+) mast hücreleri (oklar), Bar: 50 $\mu$ m.

Figure-3.a. AB/SO (+) staining for mast cells (arrows) in ventricles. Scale bar: $50 \mu \mathrm{m}$. b. Thionin (+) staining for mast cells (arrows) in atria. Scale bar: $50 \mu \mathrm{m}$. c. Thionin (+) staining for mast cells (arrows) in ventricles. Scale bar: $50 \mu$ m. d. T.B (+) staining for mast cells (arrows) in atria. Scale Bar: $50 \mu$ m. e. T.B (+) staining for mast cells (arrow) in ventricles. Scale bar: $50 \mu$ m. f. T.B (+) staining for mast cells (arrows) in ventricles. Scale bar: 50 $\mu \mathrm{m}$.

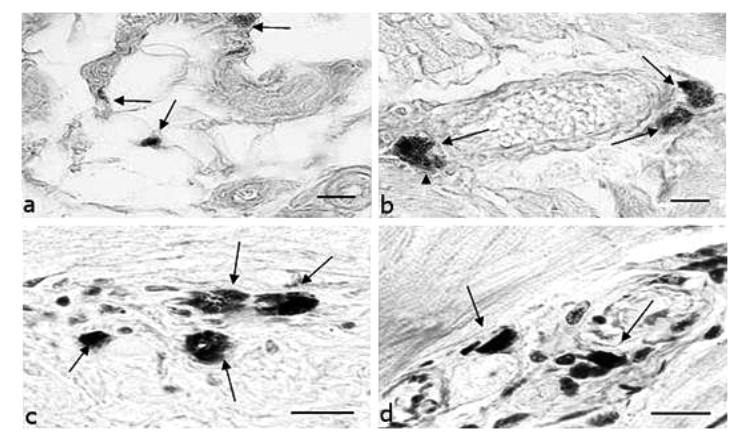

Şekil-4.a. Atriyumda Safranin (+) mast hücreleri (oklar), Bar: $25 \mu m$. b. Ventrikulusta Safranin (+) (ok başı), AB/SO (+) (oklar) mast hücreleri, Bar: 50um. c. Atriyumda Thionin (+) mast hücreleri (oklar), Bar: 50um. d. Ventrikulusta T.B (+) mast hücreleri (oklar), Bar: 50 $\mu$ m.

Figure-4.a. Safranine (+) staining for mast cells (arrows) in atria. Scale Bar: $25 \mu \mathrm{m}$. b. Safranine (+) staining for mast cells (arrow hit), AB/SO (+) staining form ast cells (arrows)

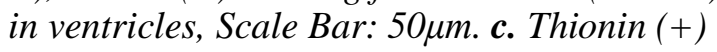
staining for mast cells (arrows) in atria. Scale bar: $50 \mu \mathrm{m}$. d. T.B (+) staining for mast cells

(arrows) in ventricles. Scale bar: 50 $\mu \mathrm{m}$. 


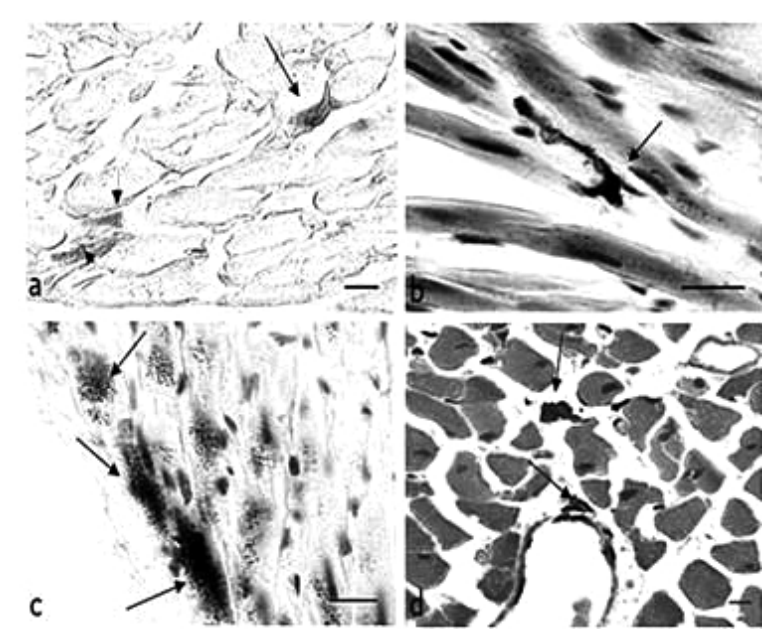

Şekil-5.a. Ventrikulusta $A B(+)$ mast hücreleri (ok başı), AB/SO (+) mast hücresi (ok), Bar: $25 \mu \mathrm{m}$. b. Ventrikulusta Thionin (+)

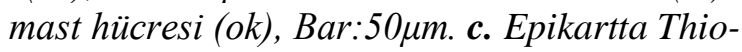
nin (+) mast hücreleri (oklar), Bar: 50 $\mu$ m. d. Ventrikulusta T.B (+) mast hücreleri (oklar), Bar: $50 \mu m$.

Figure-5.a. $A B(+)$ staining for mast cells (arrow hit), AB/SO (+) staining for mast cells (arrow) in ventricles. Scale bar: $25 \mu \mathrm{m}$. b. Thionin $(+)$ staining for mast cells (arrow) in vent-

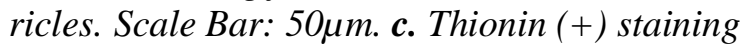
for mast cells (arrows) in epicardium. Scale

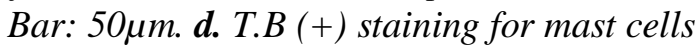
(arrows) in ventricles. Scale Bar: 50 $\mu$ m.

\section{Schaudin Fikzasyonu:}

Schaudin fikzasyonu uygulanan atriyum kesitlerine $\mathrm{AB} / \mathrm{SO}$ boyaması sonucunda yuvarlak ve armut; ventrikulusta yuvarlak veya oval; epikartta ise uzun-oval (Şekil-6.a) mast hücreleri gözlendi. Thionin boyası ile atriyumda oval; ventrikulusta oval ve yuvarlak (Şekil-6.b); epikartta ise yuvarlak mast hücreleri saptandi. Toluidine Blue uygulaması sonucunda atriyumda oval şekilli-granülleri dağınık (Şekil-6.c); ventrikulusta yuvarlak, düzensiz (Şekil-6.d); epikartta yuvarlak veya oval mast hücrelerine rastlandi.

Mast hücreleri, damar çevresinde az miktarda görülürken ventrikulus ve epikart bölgesinde daha fazla miktarda dağılım gösterdi. Mast hücrelerinin damardaki dağılımına bakıldığında ise intima ve media bölgelerinde mast hücrelerine rastlanmazken adventisyada az miktarda rastlandi.(Şekil-1.d, Şekil-3.f, Şekil-4.b, Şekil-4.d, Şekil-5.d). Damar çevresinde genellikle oval ve armut şeklinde mast hücrelerine rastland.
Mast hücre granüllerinin belirginliğini görebilmek için en iyi boyama yönteminin $\mathrm{AB} / \mathrm{SO}$ olduğu belirlendi.

Degranüle mast hücreleri sayısının granüle mast hücrelerine oranla daha az olduğu tespit edildi.

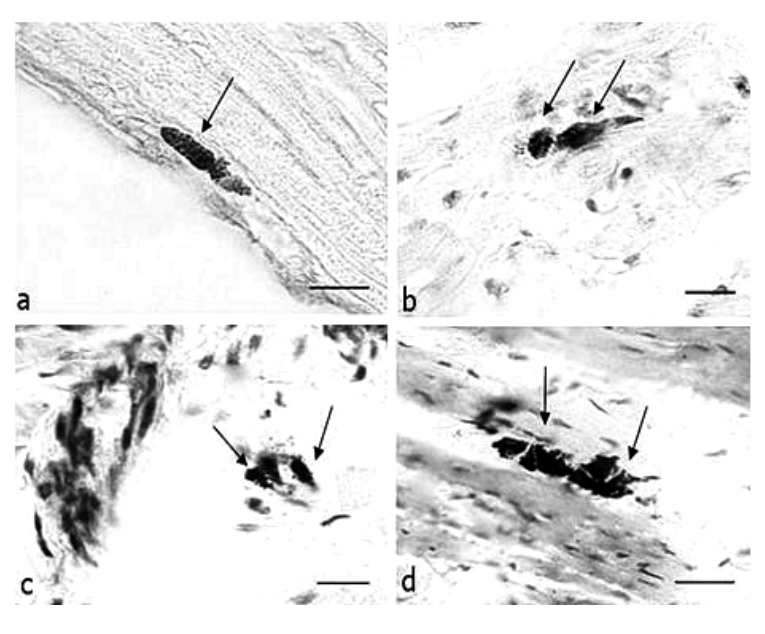

Şekil-6.a. Epikartta Safranin (+)

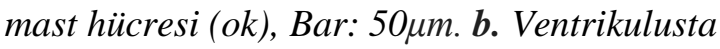
Thionin (+) mast hücreleri (oklar), Bar: 50 $\mu \mathrm{m}$. c. Atriyumda T.B (+) mast hücreleri (oklar),

Bar: $50 \mu m$.d. Ventrikulusta T.B (+) mast hücreleri (oklar), Bar: $50 \mu m$.

Figure-6.a. Safranine (+) staining for mast cells (arrow) in epicardium. Scale Bar: $50 \mu \mathrm{m}$. $\boldsymbol{b}$. Thionin (+) staining for mast cells

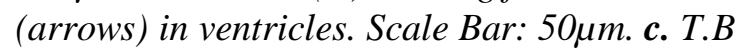
$(+)$ staining for mast cells (arrows) in atria.

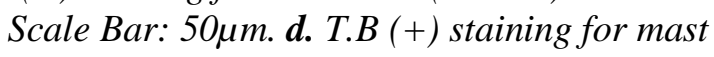
cells (arrows) in ventricles. Scale Bar: 50 $\mu \mathrm{m}$.

\section{İstatistiksel Bulgular}

Kalpte bulunan mast hücrelerinin atriyum ve ventrikulus bölgelerindeki dağılımlarını belirleme amaciyla yapılan hücre sayımlarında ulaşılan ortalama değerlerin farkılık ve sonuçlar1 Tablo 1-5. ve Şekil 1-5.'te belirtildi.

Yapılan boyalamalar sonucunda, Thionin ile boyanmış atriyumdaki mast hücrelerinin sayısal yoğunluğunun en fazla Orth tespit çözeltisiyle, ventrikulus bölgesinde ise \%10 Formalin ile fikse edilmiş doku örneklerinde olduğu belirlendi (Tablo-1, Şekil-1).

Toluidine Blue ile boyanmış atriyumda sayıca fazlalık gösteren mast hücrelerinin Carnoy fiksatifi ile, ventrikulusta ise Orth fiksatifi ile tespit edilmiş kesitlerde olduğu belirlendi (Tablo-2, Şekil-2). 
Tablo-1.Thionin boyası ile boyanan ortalama mast hücre sayıları. a, b, ab: Aynı sütunda farklı harfleri taşıyan grup ortalamaları arasında istatistiksel olarak fark vardır $(\mathbf{p}<\mathbf{0 , 0 5})$.

Table-1.Average number of mast cells stained with Thionine. a, b, ab: Different letters in the same column show to be a statistically significant difference between group means $(\mathbf{p}<0,05)$.

\begin{tabular}{|l|c|c|}
\hline \multicolumn{1}{|c|}{ THIONiN } & Atriyum & Ventrikulus \\
\hline Bouin & $15,5^{\mathrm{b}} \pm 19,7$ & $8,19^{\mathrm{b}} \pm 5,31$ \\
\hline$\% 10$ Formalin & $20,5^{\mathrm{b}} \pm 6,73$ & $43,92^{\mathrm{a}} \pm 2,93$ \\
\hline Schaudin & $19,21^{\mathrm{b}} \pm 3,95$ & $15,16^{\mathrm{b}} \pm 1,89$ \\
\hline Orth & $100,9^{\mathrm{a}} \pm 44,7$ & $36,19^{\mathrm{a}} \pm 5,31$ \\
\hline Alkolik Formalin & $64,0^{\mathrm{a}} \pm 32,1$ & $19,13^{\mathrm{b}} \pm 5,77$ \\
\hline Carnoy & $15,21^{\mathrm{b}} \pm 5,94$ & $18,20^{\mathrm{b}} \pm 2,77$ \\
\hline
\end{tabular}

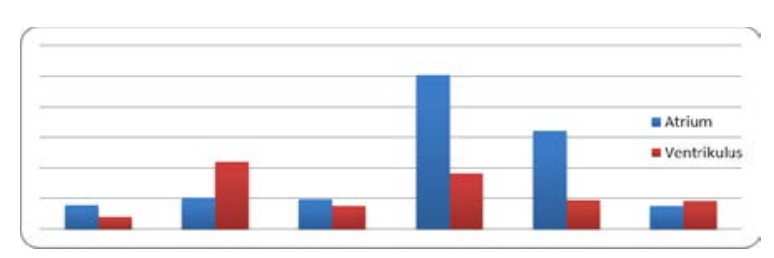

Şekil-1. Thionin boyast ile boyanan örneklerin ortalama mast hücre sayılarının dağılımları.

Figure-1. Mean distribution of mast cell numbers in sections stained with dye Thionine.

Tablo-2.Toluidine Blue boyası ile boyanan ortalama mast hücre sayıları. a: Aynı sütunda farklı harfleri taşıyan grup ortalamaları arasında istatistiksel olarak fark vardır $(p<0,05)$.

Table-2. Average number of mast cells stained with Toluidine Blue. a: Different letters in the same column show to be a statistically significant difference between group means $(\mathbf{p}<\mathbf{0 , 0 5})$.

\begin{tabular}{|l|c|c|}
\hline \multicolumn{1}{|c|}{ T.B } & Atriyum & Ventrikulus \\
\hline Bouin & $38,5^{\mathrm{a}} \pm 34,7$ & $14,917^{\mathrm{a}} \pm 1,233$ \\
\hline \%10 Formalin & $26,9^{\mathrm{a}} \pm 6,14$ & $16,67^{\mathrm{a}} \pm 1,322$ \\
\hline Schaudin & $21,8233^{\mathrm{a}} \pm 0,0950$ & $16,64^{\mathrm{a}} \pm 4,64$ \\
\hline Orth & $10,953^{\mathrm{a}} \pm 0,705$ & $17,63^{\mathrm{a}} \pm 4,03$ \\
\hline Alkolik Formalin & $21,25^{\mathrm{a}} \pm 0,00$ & $11,58^{\mathrm{a}} \pm 0,00$ \\
\hline Carnoy & $45,9^{\mathrm{a}} \pm 10,01$ & $11,303^{\mathrm{a}} \pm 1,359$ \\
\hline
\end{tabular}

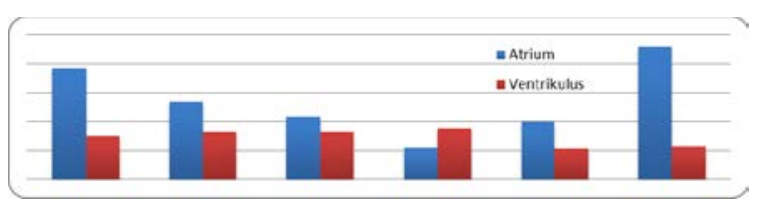

Şekil-2. Toluidine Blue boyast ile boyanan örneklerin ortalama mast hücre sayılarının dăğlımları.

Figure-2. Mean distribution of mast cell numbers in sections stained with dye Toluidine Blue.

$\mathrm{AB} / \mathrm{S}$ kombine boyası ile boyanmış kesitlerde atriyum bölgesinde kombine boyanan mast hücrelerinin sayıca en fazla Bouin fiksatifinin kullanıldığı, ventrikulus bölgesinde ise Orth fiksatifinin kullanıldığı örneklerde olduğu gözlendi (Tablo-3, Şekil-3-4). AB ile boyanan, atriyumda bulunan mast hücrelerinin sayısal fazlalığı en fazla Bouin fiksatifinin kullanıldığ ventrikulus bölgesinde ise Carnoy fiksatifinin kullanıldığı doku örneklerinde olduğu belirlendi (Tablo-4, Şekil-3-4).Safranin ile boyanan atriyum ve ventrikulus bölgelerinde ise sayısal yoğunluk en fazla Orth ile fikse edilmiş örneklerde görüldü (Tablo-5, Şekil-3-4).

Tablo-3. AB/SO boyası ile boyanan ortalama $\mathrm{AB} / \mathrm{SO}(+)$ mast hücre sayıları. a: Aynı sütunda farklı harfleri taşıyan grup ortalamaları arasında istatistiksel olarak fark vardır $(p<0,05)$.

Table-3. Average number of mast cells stained with AB/SO. a: Different letters in the same column show to be a statistically significant difference between group means $(\mathbf{p}<0,05)$.

\begin{tabular}{|l|c|c|}
\hline \multicolumn{1}{|c|}{ AB/SO } & Atriyum & Ventrikulus \\
\hline Bouin & $13,53^{\mathrm{a}} \pm 15,12$ & $8,2^{\mathrm{a}} \pm 3,73$ \\
\hline$\% 10$ Formalin & $9,570^{\mathrm{a}} \pm 0,509$ & $3,880^{\mathrm{a}} \pm 0,979$ \\
\hline Schaudin & $7,520^{\mathrm{a}} \pm 0,860$ & $1,943^{\mathrm{a}} \pm 0,255$ \\
\hline Orth & $7,98^{\mathrm{a}} \pm 5,90$ & $9,43^{\mathrm{a}} \pm 5,90$ \\
\hline Alkolik Formalin & $3,8933^{\mathrm{a}} \pm 0,1050$ & $4,963^{\mathrm{a}} \pm 1,445$ \\
\hline Carnoy & $8,58^{\mathrm{a}} \pm 4,13$ & $6,873^{\mathrm{a}} \pm 0,950$ \\
\hline
\end{tabular}




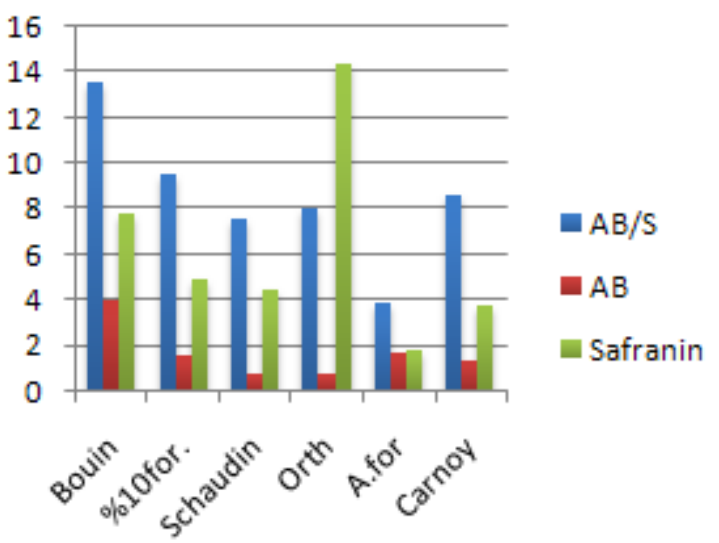

Şekil-3. Atriyumda AB/SO boyası ile boyanan örneklerin ortalama mast hücre sayılarının dağıllımları.

Figure-3. Mean distribution of mast cell numbers in sections stained with dye $A B / S O$ in atria.

Tablo-4. AB/SO boyası ile boyanan ortalama AB (+) mast hücre sayıları. a, b, ab: Aynı sütunda farklı harfleri taşıyan grup ortalamaları arasında istatistiksel olarak fark vardır $(p<0,05)$.

Table-4. Average number of mast cells stained with $\mathrm{AB}$. a, b, ab: Different letters in the same column show to be a statistically significant difference between group means $(p<0,05)$.

\begin{tabular}{|l|c|c|}
\hline \multicolumn{1}{|c|}{ AB } & Atriyum & Ventikulus \\
\hline Bouin & $4,01^{\mathrm{a}} \pm 4,64$ & $0,997^{\mathrm{a}} \pm 0,227$ \\
\hline$\% 10$ Formalin & $1,527^{\mathrm{a}} \pm 0,900$ & $0,577^{\mathrm{a}} \pm 0,238$ \\
\hline Schaudin & $0,7600^{\mathrm{a}} \pm 0,1114$ & $0,25333^{\mathrm{b}} \pm 0,00577$ \\
\hline Orth & $0,783^{\mathrm{a}} \pm 0,595$ & $0,663^{\mathrm{a}} \pm 0,435$ \\
\hline Alkolik Formalin & $1,653^{\mathrm{a}} \pm 0,625$ & $0,913^{\mathrm{a}} \pm 0,255$ \\
\hline Carnoy & $1,367^{\mathrm{a}} \pm 0,574$ & $1,203^{\mathrm{a}} \pm 0,528$ \\
\hline
\end{tabular}

Tablo-5. AB/SO kombine boyası ile boyanan ortalama Safranin $(+)$ mast hücre sayıları. a, b, ab: Aynı sütunda farklı harfleri taşıyan grup ortalamaları arasında istatistiksel olarak fark vardır $(\mathbf{p}<0,05)$.

Table-5. Average number of mast cells stained with Safranine. a, b, ab: Different letters in the same column show to be a statistically significant difference between group means $(\mathbf{p}<0,05)$.

\begin{tabular}{|l|c|c|}
\hline \multicolumn{1}{|c|}{ Safranin } & Atriyum & Ventrikulus \\
\hline Bouin & $7,82^{\mathrm{a}} \pm 6,71$ & $4,063^{\mathrm{a}} \pm 1,689$ \\
\hline$\% 10$ Formalin & $4,86^{\mathrm{a}} \pm 2,48$ & $2,123^{\mathrm{b}} \pm 0,867$ \\
\hline Schaudin & $4,453^{\mathrm{a}} \pm 0,375$ & $1,910^{\mathrm{b}} \pm 0,370$ \\
\hline Orth & $14,34^{\mathrm{a}} \pm 9,96$ & $11,56^{\mathrm{a}} \pm 7,24$ \\
\hline Alkolik Formalin & $1,823^{\mathrm{a}} \pm 0,455$ & $1,220^{\mathrm{b}} \pm 0,840$ \\
\hline Carnoy & $3,763^{\mathrm{a}} \pm 1,486$ & $3,090^{\mathrm{b}} \pm 0,440$ \\
\hline
\end{tabular}

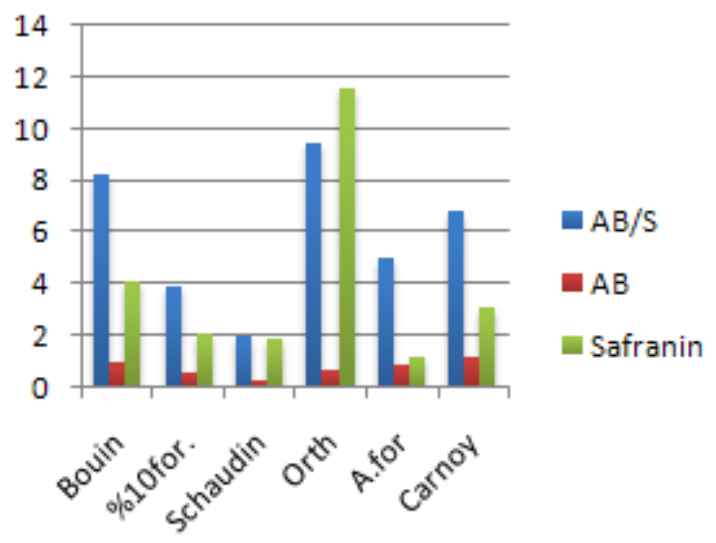

Şekil-4. Ventrikulusta AB/SO boyası ile boyanan örneklerin ortalama mast hücre sayllarının dağılımları.

Figure-4. Mean distribution of mast cell numbers in sections stained with dye AB/SO in ventricles.

\section{Tartışma ve Sonuç}

Koçak Harem ve Kurtdede ${ }^{24}$, \%10 Formalin ile fikse edilen tavuk alt solunum yollar1na ait doku örneklerinde Toluidine Blue boyamasiyla metakromatik olarak boyanan mast hücrelerine rastlamadıklarını belirtmişlerdir. $\mathrm{Bu}$ çalışmada da benzer bulgu elde edildi. Aynı araştırıcılar $^{24} \% 10$ Formalin ile fiske edilmiş doku örneklerinde mastositlerin Alcian BlueSafranin ile reaksiyon vermediklerini belirtmişlerdir. Bu çalışmada ise Alcian Blue-Safranin kombine uygulamasinda; Alcian Blue, Safranin ve $A B / S a f r a n i n$ ile kombine boyanmış olmak üzere üç farklı mastosit tespit edildi. Bu çalışmadaki bulgulara benzer biçimde Canbilen ${ }^{5}$ sıçan nasal mukozasında Alcian Blue/Safranin boyama metoduyla boyanan kesitlerdeki mast hücre granüllerinin kırmızı, mavi ve bazı hücre granüllerinin ise hem kırmızı hem mavi (kombine) boyandığını belirtmiştir.

$\mathrm{Bu}$ çalışmadaki bulguları destekler nitelikte Ertuğrul ${ }^{13}$ tavuk böbreğinde ve Uslu ve Yörük ${ }^{32}$ hindi sindirim sisteminde mast hücrelerinin bulundukları yere göre farklı büyüklüklerde, yuvarlak, oval veya mekik şeklinde gözlendiğini belirtmişlerdir.

Demirbağ vd. ${ }^{11}$ rat ince bağırsağındaki mast hücre granüllerinin tespiti için Carnoy fiksatifinin uygun olmadığını belirtirlerken bu çalışmada Carnoy fiksatifi ile mast hücre granüllerinin tespit edildiği saptand.

Ertuğrul ${ }^{13}$ tavuk böbreğinde \%10 Formalin ve izotonik formaldehit asetik asit (IFAA); 
Özen vd. ${ }^{26}$ domuz oviduktunda \%10 Formalin ve IFAA; Koçak Harem ve Kurtdede ${ }^{24}$ tavuk alt solunum yollarında IFAA; Demirbağ vd. ${ }^{11}$ rat ince bağırsağında \% 10 Formalin, Carnoy ve IFAA; Uslu ve Yörük ${ }^{31}$ hindi sindirim sisteminde \%10 Formalin, Carnoy ve Basic Lead Acetate (BLA); Eren $^{12}$ köpek derisinde \%10 tamponlu nötral formalin (NBF) ve IFAA fiksatifleri uygulamaları ve Toluidine Blue boyaması sonucunda bu çalışmadaki bulgu ile benzer tarzda mast hücrelerinde metakromazi tespit ettiklerini belirtmişlerdir.

Yine bu çalıșmada elde edilen bulgularla benzer biçimde Uslu ve Yörük ${ }^{31}$ hindi sindirim sistemi, Eren ${ }^{12}$ köpek derisi, Uslu ve Yörük ${ }^{32}$ ördek ve kazın alt solunum yolları, Saruhan ${ }^{30}$ kuzu derisi, Ertuğrul ${ }^{13}$ tavuk böbreği, Özen ${ }^{26}$ domuz oviduktu, Canbilen ${ }^{5}$ sıçan nasal mukoza ve Facoetti ${ }^{14}$ ratların kardiyak dokularında mast hücrelerinin kapilların çevresinde ve damar yakınlarında lokalize oldukları bildirilmiştir.

Facoetti vd. ${ }^{14}$, kardiyak mastositlerinin yuvarlak yapıya sahip olup, kan damarları yak1nında bulunduklarını belirtmişlerdir. Frangogionnis vd. ${ }^{18}$ de kardiyak mastositlerinin genellikle adventisyal bölgede ve damar boyunca dağ1lım gösterdiklerini belirtmişlerdir. Bu çalışmada kan damarları yakınında yerleşim gösterdikleri belirlenen mastositlerin çoğunlukla oval ve armut şeklinde oldukları ve adventisyal bölgede az sayıda görüldükleri tespit edildi.

$\mathrm{Bu}$ çalışmada elde edilen bulgulara benzer olarak Facoetti vd. ${ }^{14}$; degranülasyon sürecinde olan kardiyak mast hücre granüllerinin dağınık olarak bulunduklarını belirtmişlerdir. Ayrıca bu araştırıcılar ${ }^{14}$ degranüle olmuş ve degranüle olmamış mast hücreleri olmak üzere morfolojik açıdan iki tip mast hücresi teshiş etmişlerdir. Canbilen ${ }^{5}$ sıçan nasal mukoza degranüle mast hücreleri sayısının granüle mast hücrelerine oranla, daha az olduğunu tespit etmiştir.

Frangogiannis vd. ${ }^{18}$ kardiyak mastositlerine Toluidine Blue uyguladıklarında, Carnoy fiksatifinin kullanıldığ fiksatifinin kullanıldığ $\breve{g}_{1}$ oneklerde daha az mast hücresine rastladıklarını belirtmişlerdir. $\mathrm{Bu}$ çalışmada da benzer bulgular elde edildi.

Yapılan bu çalışma sonunda, Carnoy tespit çözeltisi ile tespit edilen kalp dokularındaki mast hücrelerinin Toluidine blue, Orth tespit çözeltisi ile tespit edilen kalp dokularındaki mast hücrelerinin ise Thionin ve $\mathrm{AB} / \mathrm{SO}$ boyama yöntemi ile daha iyi boyandığı gözlenmiştir.
Mast hücre granül şekillerinin belirginliğgini görebilmek için ise en iyi boyama yönteminin $\mathrm{AB} / \mathrm{SO}$ olduğu belirlendi.

$\mathrm{Bu}$ sonuçlara bağlı olarak; rat kardiyak mastositlerinin boyanması, sayısal yoğunluğu ve morfolojik olarak șekillerinin teșhisinde kullanılan tespit çözeltisinin büyük bir önemi bulunacağı kanısına varıldı.

\section{Kaynaklar}

1. Akay, T., 2008. Genel Histoloji. Palme Yayınc1lik, Ankara.

2. Akgül, A., 2008. Kardiyak mast hücreleri. Türkiye Klinikleri Journal Cardiovascular Sciences., 20, 63-64

3. Arda, M., 1994. İmmunolojik Reaksiyonlarda Fonksyionları olan diğer hücreler. İmmunoloji. Medisan Yayınevi, Ankara.

4. Atkins, F.M., Friedmen, M.M., Subra Rao, P.V., Metcalfe, D.D., 1985. Interaction between mast cells, fibroblast and connective tissue components. International Archives of Allergy and applied Immunology., 77, 96-102.

5. Canbilen, A., 1992. Selçuk Üniversitesi, Sağlik Bilimleri Enstitüsü, Doktora Tezi, 56, Konya.

6. Canpolat, L., 1997. Mast hücreleri. Firat Tip Dergisi., 1(4), 267-274.

7. Cook, H.C., 1961. A modified thionin technique form ast cells in tissue section. The Journal of Medical Laboratory Technology., 18, 188-192.

8. Crowle, P.K., Reed, N.D., 1984. Bone marrow origin of mucosal mast cells. International Archives of Allergy Applied Immunology., 73, 242-247.

9. Csaba, G., 1990. Alcian Blue-Safranin method for mast cells. In. Bancroft, J.D., Stevens, A. (eds.), Theory and Practice of Histological Techniques. Livingstone, New York, pp.639

10. Çolakoğlu, B., 2014. Kardiyovasküler hastalıklar ve anafilaksi. Türkiye Klinikleri Journal Immunology Allergy-Special Topics., 7(1), 44-52

11. Demirbağ, E., Çınar, K., Kutlar, M.H., Eroğlu, G., Sarı, S.M., 2012. Ratların (Rattus rattus) ince bağırsaklarında mast hücre dağılımı ve heterojenitesi. SDÜ Fen Dergisi., 7(2), 92-99

12. Eren, Ü., 2000. Köpek derisinde mast hücreleri. Ankara Üniversitesi Veteriner Fakültesi Dergisi., 47, 167-175

13. Ertuğrul, T., 2012. Tavuk böbreğinde mast hücrelerinin dağıllımı ve heterojenitesi. Veteriner $\mathrm{He}$ kimler Derneği Dergisi., 83(2), 9-16

14. Facoetti, A., Fallarini, S., Miserere, S., Bertolotti, A., Ferrero, I., Tozzi, R., Gatti, C., Palladini, G., Perlini, S., Nano, R., 2006. Histochemical study of cardiac mast cells degranulation and collagen deposition: interaction with the cathecolaminer- 
gic system in the rat. Europan Journal of Histochemistry., 50(2), 133-140

15. Forman, M.B., Oates, J.A., Robertson, R.M, Roberts, L.J., Virmani, R., 1985. Increased adventitial mast cells in a patient with coronary cpasm. New England Journal of Medicine., 313, 1138-1141

16. Frangogiannis, N.G., Lindsey M.L., Michael, L.H., Youker, K.A., Bressler, R.B., Mendoza, L.H., Spengler, R.N., Smith, C.W., Entman, M.L., 1998. Resident cardiac mast cells degranulate and release preformed TNF- alpha initiating the cytokine cascade in experimental canine myocardial ischemia/reperfusion. Circulation., 98, 699-710

17. Frangogiannis, N.G., Perrard, J.L., Mendoza, L.H., Burns, A.L., Lindsey M.L., Ballantyne, C.M., Michael, L.H., Smith, C.W., Entman, M.L., 1998. Stem cell factor induction is associated with mast cell accumulation following myocardial ischemia and reperfusion. Circulation., 98, 687-698

18. Frangogiannis, N.G., Burns, A.R., Michael L.H., Entman, M.L., 1999. Histochemical and morphological characteristics of canine cardiac mast cells. The Histochemical Journal., 31, 221-229

19. Gordon, J.R., Burd, P.R., Galli, S.J., 1990. Mast Cells as a source of multifunctional cytokines. Immunology Today., 11(12), 458-464

20. Hopwood, D.,1996. Fixation and fixatives. In. Bancroft, J.D., Stevens, A. (Eds), Theory and Practice of Histological Techniques. ChurchillLivingstone, Edinburgh, pp. 20-35.

21. Hunt, C., Campell, A.M., Robinson, C., Holgate, T., 1991. Structural and secretory characteristics of bovine lung and skin mast cells: evidence for the existence of heterogeneity. Clinical and Experimental Allergy., 21, 173- 182.

22. Irani, A.A., Schwartz, L.B., 1989. Mast cell heterogeneity, Clinical and Experimental Allergy., 19, 143-155.

23. Ito, B.R., Engler, R.L., Del Balzo, U., 1993. Role of cardiac mast cells in complement C5a-induced myocardial ischemia. American Journal of Physiology., 264, H1346-H1354

24. Koçak Harem, M., Kurtdede, N., 2004. Tavuk (Gallus domesticus) alt solunum yollarındaki mast hücreleri üzerinde histolojik araştırmalar. Erciyes Üniversitesi Veteriner Fakültesi Dergisi., 1(1), 21-26

25. Kovanen, P.T., 1995. Role of mast cells in atherosclerosis. Chemical Immunology., 62, 132-170

26. Özen, A., Bayraktaroğlu, A.G., Ertuğrul, T., Özcan, Z., Ceylan, A., Özen, D., 2014. Domuz oviduktunda mast hücreleri üzerinde 1 şı ve elektron mikroskobik çalışmalar. Ankara Üniversitesi Veteriner Fakültesi Dergisi., 61, 9-14

27. Pakiş, I., Akyıldız, E.Ü., Turan, A., Karayel, F., Ersoy, G., Kır, Z., 2008. Miyokard infarktüsünde mast hücrelerinin rolü: otopsi çalışması. Adli Tlp Bülteni., 13(1) , 9-12

28. Patella, V., Marino, I., Lamparter, B., Arbustini, E., Adt, M., Marone, G., 1995. Human heart mast cells.Isolation, purification, ultrastructure, and immunologic characterization. The Journal of Immunology., 154, 2855-2865

29. Pearce, F.L., 1986. On the heterogeneity of mast cells. Pharmaocology., 32, 61-71.

30. Saruhan, B., Akbalık M.E., Sağsöz, H., Ketani M.A., 2011. Farklı beslenme uygulanmış ivesi ırk1 kuzu derilerinde mast hücrelerinin histokimyasal ve kantitatif incelenmesi. Dicle Üniversitesi Veteriner Fakültesi Dergisi., 2(4), 58-64

31. Uslu, S., Yörük, M., 2008. Hindilerde sindirim sisteminde mast hücrelerinin dağılımı ve heterojenitesi üzerine morfolojik ve histometrik araştırmalar. Yüzüncü Yll Üniversitesi Veteriner Fakültesi Dergisi., 2008(2), 47-51

32. Uslu, S., Yörük, M., 2013. Yerli ördek (Anas platyrhynchase) ve kaz'in (Anser anser) alt solunum yolları ve akciğerlerinde bulunan mast hücrelerinin dağılımı ve heterojenitesi üzerine morfolojik ve histometrik araştırmalar. Kafkas Üniversitesi Veteriner Fakültesi Dergisi., 19(3), 475482

33. Welle, M., 1997. Development, Significance and Heterogeneity of Mast Cells with Particular Regard to the Mast Cell Specific Proteases Chymase and Tryptase. Journal of Leukocyte Biology., 61, 233-245.

34. Wolman, M., 1971. Standart Blue. Laboratory Investigation., 25, 104-110. 
